\title{
Article \\ Use of a Sequential Fermentation Method for the Production of Aspergillus tamarii URM4634 Protease and a Kinetic/ Thermodynamic Study of the Enzyme
}

\author{
Rodrigo Lira de Oliveira ${ }^{1}$, Emiliana de Souza Claudino ${ }^{1}$, Attilio Converti ${ }^{2, *}$ (D) and Tatiana Souza Porto ${ }^{3}$ (D) \\ 1 School of Food Engineering, Federal University of Agreste of Pernambuco/UFAPE, Av. Bom Pastor, \\ Boa Vista, s/n, Garanhuns 55296-901, Brazil; rodrigolira1@outlook.com (R.L.d.O.); \\ emilianasouzaclau@hotmail.com (E.d.S.C.) \\ 2 Department of Civil, Chemical and Environmental Engineering, Pole of Chemical Engineering, Genoa \\ University, Via Opera Pia 15, 16145 Genoa, Italy \\ 3 Department of Morphology and Animal Physiology, Federal Rural University of Pernambuco/UFRPE, \\ Av. Dom Manoel de Medeiros, s/n, Recife 52171-900, Brazil; tatiana.porto@ufrpe.br \\ * Correspondence: converti@unige.it; Tel.: +39-010-3352593
}

Citation: de Oliveira, R.L.; de Souza Claudino, E.; Converti, A.; Porto, T.S. Use of a Sequential Fermentation Method for the Production of Aspergillus tamarii URM4634 Protease and a Kinetic/Thermodynamic Study of the Enzyme. Catalysts 2021, 11, 963 https://doi.org/10.3390/ catal11080963

Academic Editors: Chun-Yung

Huang, Chwen-Jen Shieh, Cheng-Di Dong and Chia-Hung Kuo

Received: 27 June 2021

Accepted: 10 August 2021

Published: 11 August 2021

Publisher's Note: MDPI stays neutral with regard to jurisdictional claims in published maps and institutional affiliations.

Copyright: (c) 2021 by the authors. Licensee MDPI, Basel, Switzerland. This article is an open access article distributed under the terms and conditions of the Creative Commons Attribution (CC BY) license (https:// creativecommons.org/licenses/by/ $4.0 /)$
Abstract: Microbial proteases are commonly produced by submerged ( $\mathrm{SmF}$ ) or solid-state fermentation (SSF), whose combination results in an unconventional method, called sequential fermentation (SF), which has already been used only to produce cellulolytic enzymes. In this context, the aim of the present study was the development of a novel SF method for protease production using wheat bran as a substrate. Moreover, the kinetic and thermodynamic parameters of azocasein hydrolysis were estimated, thus providing a greater understanding of the catalytic reaction. In SF, an approximately 9-fold increase in protease activity was observed compared to the conventional SmF method. Optimization of glucose concentration and medium volume by statistical means allowed us to achieve a maximum protease activity of $180.17 \mathrm{U} \mathrm{mL}^{-1}$. The obtained enzyme had an optimum $\mathrm{pH}$ and temperature of 7.0 and $50{ }^{\circ} \mathrm{C}$, respectively. Kinetic and thermodynamic parameters highlighted that such a neutral protease is satisfactorily thermostable at $50{ }^{\circ} \mathrm{C}$, a temperature commonly used in many applications in the food industry. The results obtained suggested not only that SF could be a promising alternative to produce proteases, but also that it could be adapted to produce several other enzymes.

Keywords: Aspergillus; protease; sequential fermentation; kinetics; thermodynamics

\section{Introduction}

Proteases are enzymes that catalyze the hydrolysis of proteins resulting in their breakdown into peptides and amino acids. They represent an important group of industrial enzymes, accounting for almost $60 \%$ of the entire enzyme market and $40 \%$ of the global enzyme sales [1]. Proteases are in fact used in various industrial sectors, including those of detergents, leather goods, food, fine chemicals, pharmaceuticals, and cosmetics, and can be obtained from different sources such as plants, animal, and microorganisms, with the latter source contributing to nearly two-third of industrially used proteases. This is mainly due to the possibility of producing them quickly in large amounts by established fermentation processes that also allow for their regular supply [2,3]. Filamentous fungi have an extraordinary capability to secrete different types of proteases, with the main fungal strains for their industrial production belonging to the genera Trichoderma and Aspergillus [2].

Commonly, microbial proteases are produced by submerged fermentation (SmF), a process in which microorganisms grow in a liquid medium with high free water content, or by solid state fermentation (SSF), where they grow in an environment without free water or with a very low content of free water [4]. Both processes have their own advantages 
and disadvantages depending on the operating conditions. SmF has advantages related to the presence of instrumentation and process control, and consequently it is the preferred process for industrial enzyme production. On the other hand, SSF can be particularly advantageous to cultivate filamentous fungi, because it simulates their natural habitat leading to higher enzyme productivity compared to $\mathrm{SmF}[5,6]$.

A combination of these two cultivation methods, called sequential fermentation (SF or SeqF), was proposed initially by Cunha et al. [7] and applied effectively to produce cellulolytic enzymes. It is characterized by a preculture preparation with an initial step of fungal growth under solid state, followed by a submerged step [8]. This fermentation technique, so far, has been poorly documented and used exclusively to produce lignocellulolytic enzymes using filamentous fungi such as Aspergillus niger and Trichoderma reesei $[9,10]$ or the white rot fungus Pleurotus ostreatus [11]. Different configurations were validated for this approach, using shake flasks, stirred tanks and bubble column bioreactors, which allowed an increase in enzyme productivity compared to the conventional SmF [8]. Most studies have reported the use of sugarcane bagasse as a substrate, nonetheless other substrates such as wheat bran and soybean bran have also been used successfully [12].

Although SF is used for a specific category of enzymes [8], it could be adapted to produce different enzymes of industrial interest. Based on that background, sequential fermentation is used for the first time in this study to produce Aspergillus tamarii protease. Particularly, the aims of this study were: (a) to test the sequential fermentation method for protease production by an Aspergillus tamarii strain using wheat bran as a substrate, (b) to biochemically characterize the crude extract, and (c) to determine and investigate the kinetic and thermodynamic parameters related to both substrate hydrolysis and enzyme thermal denaturation.

\section{Results and Discussion}

\subsection{Protease Production by Sequential Fermentation}

Protease production by Aspergillus tamarii URM4634 in submerged fermentation (SmF) and sequential fermentation (SF) was evaluated after $48 \mathrm{~h}$ of cultivation for comparison purposes. Even though other fermentation times were evaluated (data not shown), $48 \mathrm{~h}$ was shown to be the most suitable for enzyme production in both fermentation processes. SF allowed an almost double enzyme production ( $39.08 \mathrm{U} \mathrm{mL}^{-1}$ ) compared to SmF $\left(20.0 \mathrm{U} \mathrm{mL}^{-1}\right)$, confirming the positive trend observed by several authors who used this approach to produce cellulolytic enzymes $[8,10,12]$. A possible explanation for this increase is related to the morphology of filamentous fungi, since in SF there was a predominance of dispersed filamentous mycelium, while in the conventional SmF early formation of fungal pellets took place [9]. However, the dispersed hyphal morphology results in a more viscous medium that can make mixing and aeration difficult [8]; furthermore, other factors should be considered for a complete understanding of SF, especially if intended for the production of proteolytic enzymes.

Glucose concentration, medium volume and inoculum size were selected as the independent variables for protease production by SF, because they are among those that mostly influence the conventional fermentation processes. Their effects on such a response were investigated through cultivations carried out according to a $2^{3}$-full factorial design whose results are listed in Table 1 . The highest protease production $\left(127.67 \mathrm{U} \mathrm{mL}^{-1}\right)$ was obtained in the run 6 performed using a glucose concentration of $50 \mathrm{~g} \mathrm{~L}^{-1}$, a medium volume of $15 \mathrm{~mL} \mathrm{~g}^{-1}$ of substrate and an inoculum size of $10^{8}$ spores $\mathrm{g}^{-1}$ of substrate. According to the statistical analysis (Table 2), all the individual variables and their interactions were statistically significant. In particular, glucose concentration showed a positive effect probably because, as known, in fermentation processes the carbon source not only acts as the major constituent for the construction of cell material but is also used in the synthesis of polysaccharides and as an energy source [13]. However, it should be remembered that glucose can have a repressive effect on the synthesis of other enzymes such as pectinases [14] A similar positive effect was exerted by the inoculum size, while the medium volume 
had a negative influence on protease production. A larger inoculum size reduces the time that cells take to consume all the substrate and produce the enzyme of interest. However, beyond a certain limit, enzyme production can decrease due to the depletion of nutrients needed for biomass growth, which results in a decrease in metabolic activity $[15,16]$. To the best of our knowledge, this is the first report on the evaluation of the influence of medium volume on SF, and the trend observed at lower medium volumes may be related to the prevention of enzyme dilution in the culture medium itself.

Table 1. Experimental conditions and results of protease production by Aspergillus tamarii URM4634 in sequential fermentations using wheat bran as a substrate. Runs were carried out according to a $2^{3}$-full factorial design plus three central points.

\begin{tabular}{|c|c|c|c|c|}
\hline Run & $\begin{array}{c}\text { Glucose } \\
\text { Concentration } \\
\left(\mathrm{g} \mathrm{L}^{-1}\right)\end{array}$ & $\begin{array}{l}\text { Medium Volume } \\
\text { (mL g }{ }^{-1} \text { of } \\
\text { Substrate) }\end{array}$ & $\begin{array}{l}\text { Inoculum Size } \\
\text { (Spores } \mathrm{g}^{-1} \text { of } \\
\text { Substrate) }\end{array}$ & $\begin{array}{l}\text { Protease Activity } \\
\quad\left(\mathrm{U} \mathrm{mL}^{-1}\right)\end{array}$ \\
\hline 1 & 30 & 15 & $10^{6}$ & $33.33 \pm 0.94$ \\
\hline 2 & 50 & 15 & $10^{6}$ & $25.33 \pm 3.53$ \\
\hline 3 & 30 & 25 & $10^{6}$ & $18.00 \pm 4.95$ \\
\hline 4 & 50 & 25 & $10^{6}$ & $12.67 \pm 1.17$ \\
\hline 5 & 30 & 15 & $10^{8}$ & $90.33 \pm 4.95$ \\
\hline 6 & 50 & 15 & $10^{8}$ & $127.67 \pm 11.66$ \\
\hline 7 & 30 & 25 & $10^{8}$ & $80.67 \pm 0.47$ \\
\hline 8 & 50 & 25 & $10^{8}$ & $78.67 \pm 1.64$ \\
\hline 9 & 40 & 20 & $10^{7}$ & $35.67 \pm 1.88$ \\
\hline 10 & 40 & 20 & $10^{7}$ & $39.67 \pm 3.29$ \\
\hline 11 & 40 & 20 & $10^{7}$ & $43.00 \pm 3.06$ \\
\hline 12 & 40 & 20 & $10^{7}$ & $38.00 \pm 3.30$ \\
\hline
\end{tabular}

Table 2. Effects of the independent variables and their interactions on protease production by Aspergillus tamarii URM4634 in sequential fermentations carried out according to the $2^{3}$-full factorial design shown in Table 1 using wheat bran as a substrate.

\begin{tabular}{ccc}
\hline Variable or Interaction & Estimates & $p$-Value \\
\hline (1) Glucose concentration & $4.74^{*}$ & 0.0047 \\
(2) Medium volume & $-18.68^{*}$ & 0.0021 \\
(3) Inoculum size & $62.06^{*}$ & 0.0006 \\
$1 \times 2$ & $-7.90^{*}$ & 0.0245 \\
$1 \times 3$ & $10.49^{*}$ & 0.0113 \\
$2 \times 3$ & $-6.61^{*}$ & 0.0390 \\
$1 \times 2 \times 3$ & $-9.05^{*}$ & 0.0170 \\
\hline
\end{tabular}

* Statistically significant estimates at 95\% confidence level $(p<0.05)$.

Interaction effects are interpreted differently from what is usually done with the individual variables. A positive interaction between two variables means that they have a synergistic effect, i.e., the levels of both must increase or decrease together to enhance the response. A negative interaction, on the other hand, means that the variables have an antagonistic effect, i.e., the level of one variable must increase and that of the other decrease to enhance the response. In the case of interaction among three variables, the negative sign means that one of them has an antagonistic effect with the others. More specifically, as shown by the results of Table 2, the medium volume had a negative effect, while the other variables a positive effect. The interaction had a negative sign, but the behavior of each variable involved in the interaction must be evaluated. The interaction among the three factors can be better seen in the cubic graph depicted in Figure 1. 


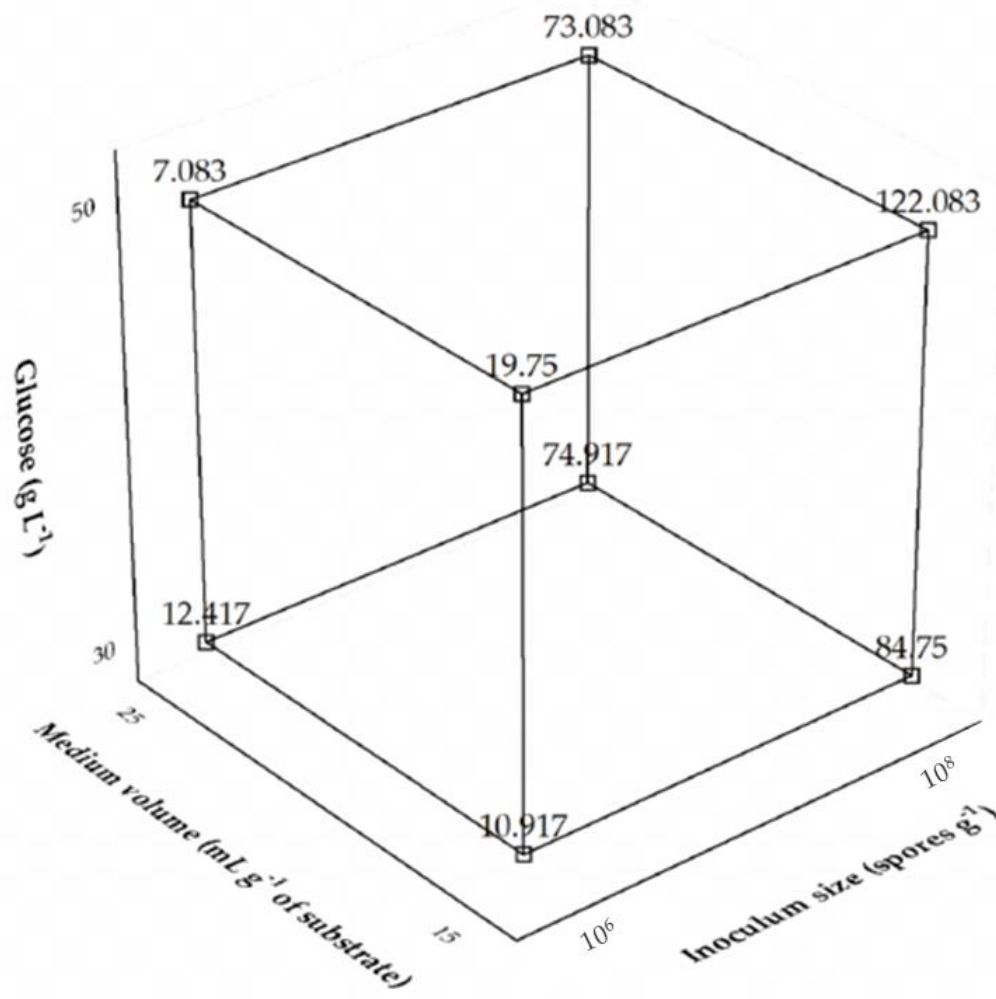

Figure 1. Cubic plot of the effects of glucose concentration, medium volume, and inoculum size on the production of Aspergillus tamarii URM4634 protease by sequential fermentation.

The antagonist ternary interaction among the independent variables confirms the highest levels of glucose and inoculum size and the lowest one of medium volume as the best fermentation conditions. For optimization purposes and due to the difficulty of carrying out industrial production at higher spore concentrations, a $2^{2}$-CCRD was performed using only glucose concentration and medium volume as the independent variables, while keeping the inoculum size constant at the highest level $\left(10^{8}\right.$ spores $\left.\mathrm{g}^{-1}\right)$, whose experimental conditions and results are listed in Table 3. The highest protease activity (180.17 $\mathrm{U} \mathrm{mL}^{-1}$ ) was observed in the run 4 carried out at a glucose concentration of $55 \mathrm{~g} \mathrm{~L}^{-1}$ and a medium volume of $17.5 \mathrm{~mL}$ per $\mathrm{g}$ of substrate.

Table 3. Experimental conditions and results of protease production by Aspergillus tamarii URM4634 in sequential fermentations using wheat bran as a substrate. Optimization tests were carried out according to a central composite rotational design.

\begin{tabular}{cccc}
\hline Run & $\begin{array}{c}\text { Glucose Concentration } \\
\left(\mathbf{g ~ L ~}^{-\mathbf{1}} \mathbf{)}\right.\end{array}$ & $\begin{array}{c}\text { Medium Volume } \\
\left(\mathbf{m L ~}^{-\mathbf{1}} \mathbf{~ o f ~ S u b s t r a t e )}\right.\end{array}$ & $\begin{array}{c}\text { Protease Activity } \\
\left(\mathbf{U ~ m ~}^{-\mathbf{1}}\right)\end{array}$ \\
\hline 1 & 45 & 12.5 & $151.00 \pm 14.66$ \\
2 & 45 & 17.5 & $89.17 \pm 6.36$ \\
3 & 55 & 12.5 & $169.50 \pm 10.13$ \\
4 & 55 & 17.5 & $180.17 \pm 4.94$ \\
5 & 42.05 & 15.0 & $135.50 \pm 7.77$ \\
6 & 57.05 & 15.0 & $94.00 \pm 8.66$ \\
7 & 50 & 11.475 & $156.67 \pm 11.66$ \\
8 & 50 & 18.525 & $103.83 \pm 5.42$ \\
9 & 50 & 15.0 & $134.17 \pm 16.5$ \\
10 & 50 & 15.0 & $128.44 \pm 2.35$ \\
11 & 50 & 15.0 & $139.50 \pm 10.78$ \\
\hline
\end{tabular}


The analysis of variance (ANOVA) (Table 4) indicates that the quadratic model showed a significant lack of fit and an unsatisfactory adjustment to the experimental data $\left(\mathrm{R}^{2}=0.44\right)$, therefore, the response surface was not shown. Nonetheless, the experiments performed were effective in increasing protease production by as much as 4.6 times compared to the initial SF runs. Only the medium volume showed a significant linear negative effect $(-8.05)$, and its interaction with glucose concentration, contrary to the statistical analysis of the $2^{3}$-full factorial design, was significant and synergistic (6.55) (results not shown), likely due to the different experimental regions investigated.

Table 4. Results of the analysis of variance applied to the results of the central composite rotational design used for protease production by Aspergillus tamarii URM4634 in sequential fermentations using wheat bran as a substrate.

\begin{tabular}{cccccc}
\hline Source & $\begin{array}{c}\text { Sum of } \\
\text { Squares }\end{array}$ & $\begin{array}{c}\text { Degrees of } \\
\text { Freedom }\end{array}$ & $\begin{array}{c}\text { Mean } \\
\text { Square }\end{array}$ & F-Value & $p$-Value \\
\hline GC(L) & 322.71 & 1 & 322.71 & 10.55 & 0.083 \\
GC(Q) & 65.40 & 2 & 65.40 & 2.14 & 0.281 \\
MV(L) & 1980.86 & 1 & 1980.86 & 64.75 & 0.015 \\
MV(Q) & 106.70 & 1 & 106.70 & 3.49 & 0.203 \\
GC(L) $\times$ MV(L) & 1314.06 & 1 & 1314.06 & 42.95 & 0.022 \\
Lack of fit & 4851.15 & 3 & 1617.05 & 52.85 & 0.019 \\
Pure error & 61.19 & 2 & 30.59 & & \\
Total & 8772.15 & 10 & & & \\
\hline GC $=$ Glucose concentration; MV $=$ Medium volume; L = Linear effect; Q = Quadratic effect.
\end{tabular}

\subsection{Effect of Temperature and $\mathrm{pH}$ on Protease Activity}

The rate of enzyme-catalyzed reactions can be influenced by various environmental factors through reversible or irreversible changes in protein structure, of which temperature and $\mathrm{pH}$ are the most important [17]. The effect of a temperature rise on enzyme activity is the result of two phenomena acting simultaneously but in opposite directions, i.e., an increase in the reaction rate and a progressive enzyme inactivation due to its denaturation. On the other hand, the enzyme activity is influenced by $\mathrm{pH}$ because the ionization state of amino acids constituting the enzyme structure depends on the concentration of hydrogen ions $[17,18]$. In the present study, the optimal temperature and $\mathrm{pH}$ of $A$. tamarii URM4634 protease were shown to be $50{ }^{\circ} \mathrm{C}$ (Figure 2A) and 7.0 (Figure 2B), respectively.

In a previous study by our research group, the protease obtained by SSF using the same fungal strain and substrate (wheat bran) showed different optimal conditions $\left(40{ }^{\circ} \mathrm{C}\right.$ and $\mathrm{pH}$ 8.0) [19], suggesting that the fermentation method may directly influence the characteristics of the biocatalyst. A similar optimum temperature was observed for proteases obtained from different Aspergillus species, such as A. heteromorphus [20], A. niger [21] and A. oryzae [22], in conventional fermentation processes (SSF and SmF).

Based on these and previous results, the A. tamarii URM4634 protease under investigation was characterized as a neutral protease, being active under neutral, weakly acidic or weakly alkaline conditions. Proteases belonging to this family are considered especially important for the food industry, mainly for baking and brewing processes, as they lead to less bitter food protein hydrolysates thanks to an intermediate reaction rate and are poorly sensitive to plant proteinase inhibitors $[23,24]$. Fungal neutral proteases, of which $A$. oryzae is the most important producer [25], are constituents of various enzyme preparations, and the search for new sources of proteases has aroused considerable interest. Therefore, the neutral protease from $A$. tamarii URM4634 obtained in this study by the SF method may be an interesting alternative for further studies involving applications in the food industry. A neutral protease from another $A$. tamarii strain was already produced by our research group by extractive fermentation [26], which provides confirmation of the potential of this species as a producer of neutral proteases. 

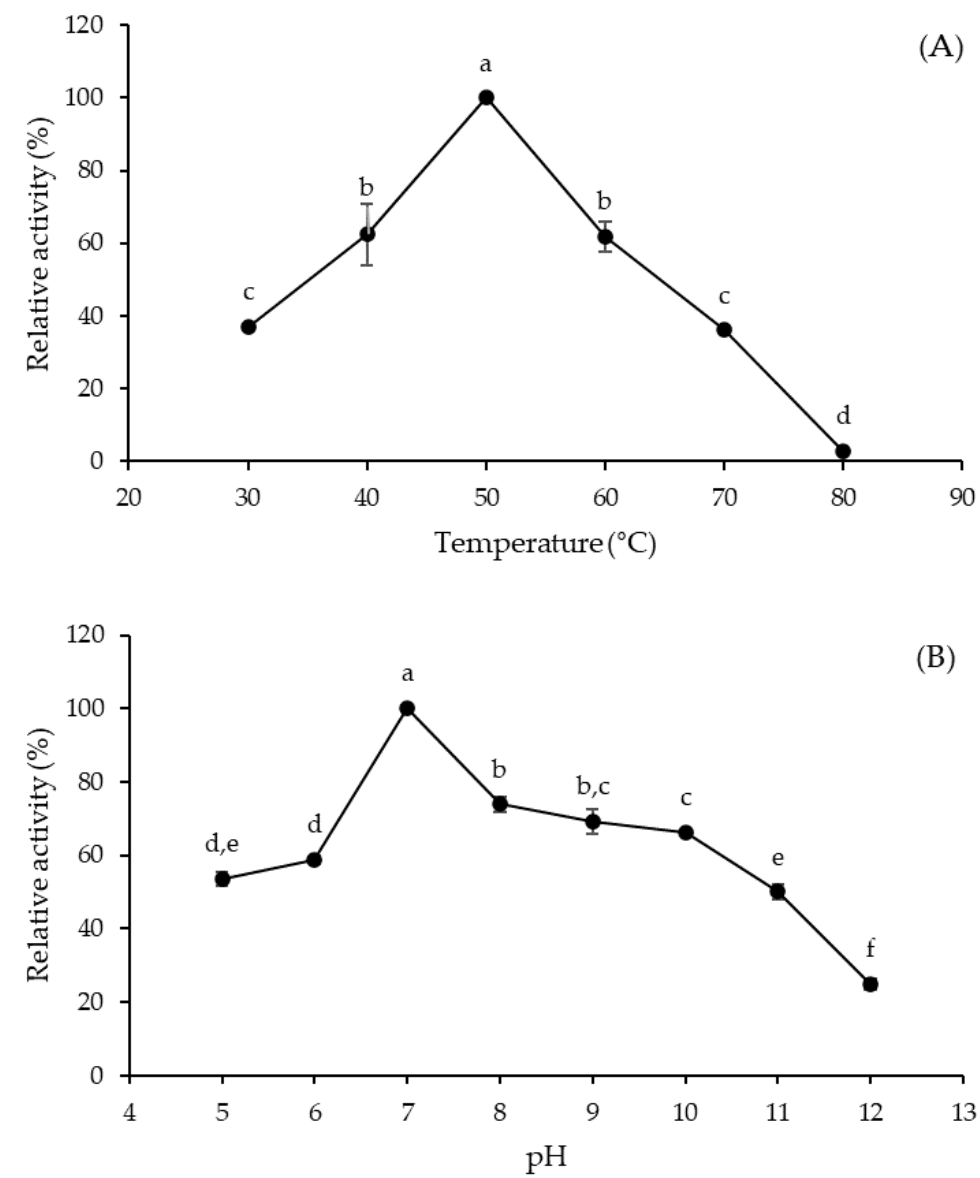

Figure 2. Effects of temperature (A) and $\mathrm{pH}(\mathbf{B})$ on the activity of Aspergillus tamarii URM4634 protease produced by sequential fermentation using wheat bran as a substrate. Different letters (a-f) indicate statistically significant differences $(p<0.05)$.

\subsection{Kinetic and Thermodynamic Parameters of Azocasein Hydrolysis}

The crude extract obtained by SF showed a typical Michaelis-Menten kinetic profile, and the kinetic parameters of azocasein hydrolysis were estimated from the slope of Lineweaver-Burk plot (Figure 3A) with satisfactory correlation $\left(R^{2}=0.993\right)$. As shown in Table 5 , the enzyme exhibited values of the Michaelis constant $\left(\mathrm{K}_{\mathrm{m}}\right)$, maximum rate $\left(\mathrm{V}_{\max }\right)$ and turnover number $\left(\mathrm{k}_{\text {cat }}\right)$ of $16.26 \mathrm{mg} \mathrm{mL}^{-1}, 147.06 \mathrm{mg} \mathrm{mL}^{-1} \mathrm{~min}^{-1}$ and $195.37 \mathrm{~s}^{-1}$, respectively. Such a $K_{m}$ value is lower than that obtained in SSF $\left(18.7 \mathrm{mg} \mathrm{mL}^{-1}\right)$ [19] using the same fungal strain and substrate, while that of $V_{\max }$ is 5.15 -fold higher $\left(28.57 \mathrm{mg} \mathrm{mL}^{-1}\right.$ $\mathrm{min}^{-1}$ ) [19]. These results indicate an increase in the affinity for substrate and the catalytic potential of protease produced by SF compared to that produced by SSF. The value of $k_{\text {cat }}$ $\left(195.37 \mathrm{~s}^{-1}\right)$, which corresponds to the maximum number of substrate molecules converted into product per active site per unit of time, is almost $20 \%$ higher than that reported by Lee et al. [27] for purified A. oryzae protease obtained by $\mathrm{SmF}$ using casein as a substrate $\left(163.5 \mathrm{~s}^{-1}\right)$.

From the slope of the straight line to the right of the Arrhenius-type plot (Figure 3B), an activation energy ( $E_{a}^{*}$ ) of $40.38 \mathrm{~kJ} \mathrm{~mol}^{-1}$ was estimated for azocasein hydrolysis (Table 5). This value is lower than that reported for casein hydrolysis by $A$. fumigatus protease $\left(62 \mathrm{~kJ} \mathrm{~mol}^{-1}\right)$ [28] and slightly higher than that of bread protein hydrolysis by A. awamori protease $\left(36.8 \mathrm{~kJ} \mathrm{~mol}^{-1}\right)$ [29]. It is worth remembering, for comparative purposes, that a lower $\mathrm{E}_{\mathrm{a}}^{*}$ value indicates that less energy is required to form the activated complex of azocasein hydrolysis, so the reaction is favored. Another important parameter to evaluate the temperature influence on a catalyzed reaction is the temperature quotient $\left(\mathrm{Q}_{10}\right)$, which indicates the rate increase resulting from a $10{ }^{\circ} \mathrm{C}$ temperature rise. At temperatures 
between 30 and $50{ }^{\circ} \mathrm{C}$, the mean value of $\mathrm{Q}_{10}$ (1.17) was very close to those reported by de Castro et al. [30] for $A$. niger protease (1.20 to 1.28) in the temperature range of $35-55^{\circ} \mathrm{C}$. It has been stressed that deviations of $Q_{10}$ values from the typical range of enzyme reactions (1.0 to 2.0) are indicative of the involvement of factors other than temperature in the control of the reaction rate [31]. Therefore, it can be inferred that azocasein hydrolysis by A. tamarii protease was kinetically controlled by temperature within the entire temperature range investigated.
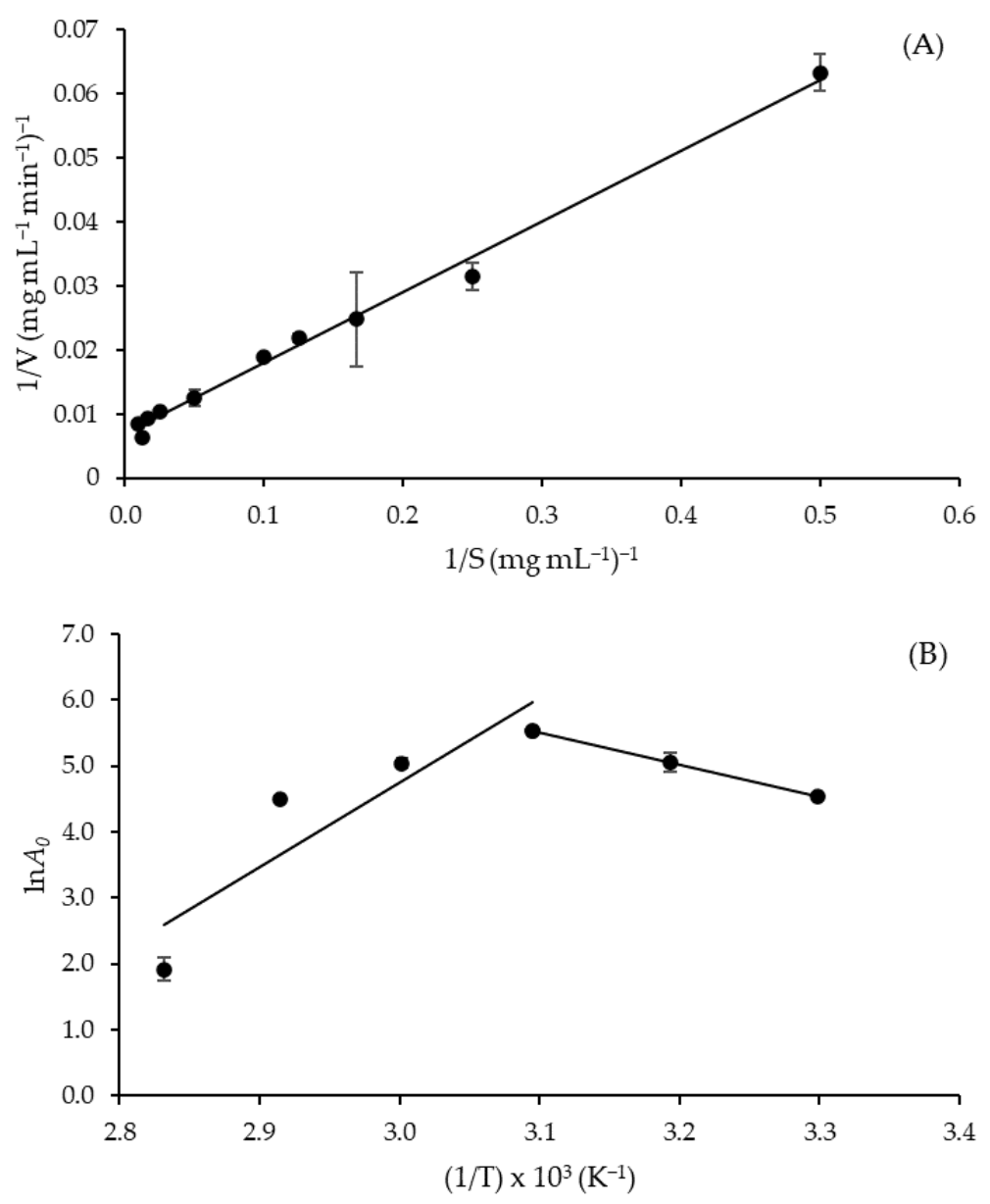

Figure 3. (A) Lineweaver-Burk plot to calculate $\mathrm{K}_{\mathrm{m}}$ and $\mathrm{V}_{\max }$ of Aspergillus tamarii URM4634 protease produced by sequential fermentation using azocasein as a substrate $\left(R^{2}=0.993\right)$, and (B) Arrhenius-type plot (on the right) to estimate the activation energy of the azocasein hydrolysis reaction $\left(R^{2}=0.998\right)$.

Table 5. Kinetic and thermodynamic parameters of the azocasein hydrolysis reaction catalyzed by the Aspergillus tamarii URM4634 protease produced by sequential fermentation using wheat bran as a substrate. $25^{\circ} \mathrm{C}$ was selected as a reference temperature.

\begin{tabular}{cc}
\hline Parameter & Value \\
\hline${ }^{\mathrm{a}} \mathrm{K}_{\mathrm{m}}\left(\mathrm{mg} \mathrm{mL}^{-1}\right)$ & 16.26 \\
${ }^{\mathrm{b}} \mathrm{V}_{\max }\left(\mathrm{mg} \mathrm{mL}^{-1} \mathrm{~min}^{-1}\right)$ & 147.06 \\
${ }^{\mathrm{c}} \mathrm{k}_{\mathrm{cat}}\left(\mathrm{s}^{-1}\right)$ & 195.37 \\
$\mathrm{~d} \mathrm{E}^{*}\left(\mathrm{~kJ} \mathrm{~mol}^{-1}\right)$ & 40.38 \\
$\mathrm{e} \Delta \mathrm{G}^{*}\left(\mathrm{~kJ} \mathrm{~mol}^{-1}\right)$ & 59.94 \\
$\mathrm{f} \Delta \mathrm{H}^{*}\left(\mathrm{~kJ} \mathrm{~mol}^{-1}\right)$ & 37.90 \\
$\mathrm{~g} \Delta \mathrm{S}^{*}\left(\mathrm{~J} \mathrm{~K}^{-1} \mathrm{~mol}^{-1}\right)$ & -73.94 \\
\hline
\end{tabular}

${ }^{a}$ Michaelis constant; ${ }^{\mathrm{b}}$ Maximum rate; ${ }^{\mathrm{c}}$ Turnover number; ${ }^{\mathrm{d}}$ Activation energy; ${ }^{\mathrm{e}}$ Activation Gibbs free energy;

${ }^{\mathrm{f}}$ Activation enthalpy; ${ }^{\mathrm{g}}$ Activation entropy. 
The other thermodynamic parameters of azocasein hydrolysis, namely activation enthalpy $\left(\Delta \mathrm{H}^{*}\right)$, entropy $\left(\Delta \mathrm{S}^{*}\right)$ and Gibbs free energy $\left(\Delta \mathrm{G}^{*}\right)$, were also calculated by Equations (2) to (4) and listed in Table 5.

The relatively low $\Delta \mathrm{H}^{*}$ value $\left(37.90 \mathrm{~kJ} \mathrm{~mol}^{-1}\right)$ indicates that the formation of the transition state or activated enzyme-substrate complex occurred effectively; however, this value is higher than that reported by Fernandes et al. [20] for azocasein hydrolysis by $A$. heteromorphus protease $\left(21.8 \mathrm{~kJ} \mathrm{~mol}^{-1}\right)$. As known, $\Delta \mathrm{S}^{*}$ is correlated to the order degree of a reaction system; therefore, in enzyme-catalyzed reactions negative values such as that estimated in this study $\left(-73.94 \mathrm{~J} \mathrm{~K}^{-1} \mathrm{~mol}^{-1}\right)$ suggest that the structure of enzyme-substrate at transition state is more ordered than that of the enzyme-substrate complex. Similar qualitative behavior was observed for proteases [32] and other hydrolases such as $\beta$-fructofuranosidases [31], pectinases [33] and levansucrases [34]. As known, $\Delta G^{*}$ is the most suitable thermodynamic parameter to measure the feasibility and extent of a reaction, as the lower the $\Delta \mathrm{G}^{*}$ value the more feasible the reaction, i.e., the conversion of the reactant into the product is more spontaneous [35]. The value of $\Delta \mathrm{G}^{*}$ estimated for azocasein hydrolysis catalyzed by A. tamarii URM4634 protease $\left(59.94 \mathrm{~kJ} \mathrm{~mol}^{-1}\right)$ is lower than those of casein and azocasein hydrolysis catalyzed by other fungal (A. heteromorphus: $\Delta \mathrm{G}^{*}=65.8 \mathrm{~kJ} \mathrm{~mol}^{-1}$ [20]) and bacterial (Bacillus stearothermophilus: $\Delta \mathrm{G}^{*}=91.71 \mathrm{~kJ} \mathrm{~mol}^{-1}$ [32]; Bacillus cereus: $\Delta \mathrm{G}^{*}=68.68-69.42 \mathrm{~kJ} \mathrm{~mol}^{-1}$ [36]) proteases, which indicates that the conversion of the transition state of enzyme-substrate complex into the product is more spontaneous.

\subsection{Kinetic and Thermodynamic Parameters of Protease Thermal Denaturation}

The time-dependent thermal inactivation of biocatalysts (denaturation) can be a major problem in enzyme-catalyzed processes, and knowledge of the impact of this phenomenon is particularly useful before running any industrial-scale bioprocess. Then, to evaluate the protease thermostability, residual activity tests were performed in the temperature range of 50 to $80{ }^{\circ} \mathrm{C}$, the results of which are shown in semi-log plots (Figure 4).

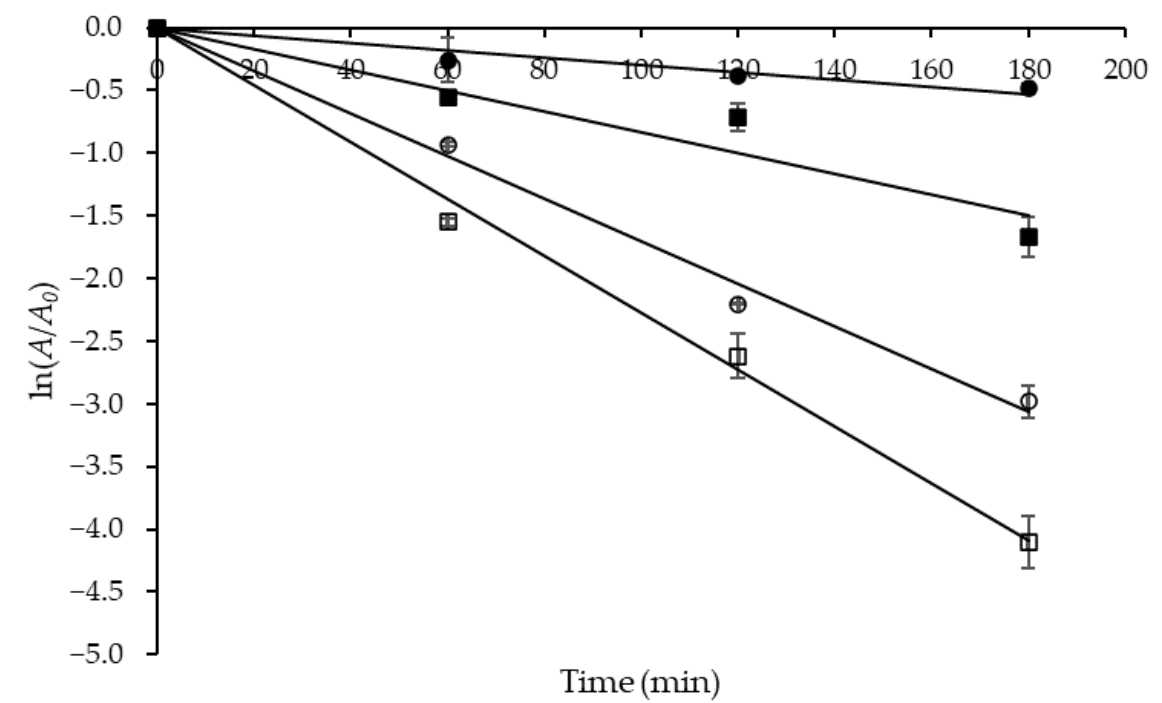

Figure 4. Semi-log plots of the coefficient of residual activity (A/ $\left.\mathrm{A}_{0}\right)$ of Aspergillus tamarii URM4634 protease versus time used to estimate the first-order inactivation rate constant $\left(\mathrm{k}_{\mathrm{d}}\right)$ at different temperatures $\left({ }^{\circ} \mathrm{C}\right):(\bullet) 50 ;(\square) 60 ;(\bigcirc) 70 ;(\square) 80$.

The slopes of the straight lines obtained at different temperatures were used to estimate the first-order inactivation rate constant $\left(\mathrm{k}_{\mathrm{d}}\right)$, whose values were estimated with a satisfactory correlation $\left(0.969 \leq R^{2} \leq 0.998\right)$ and are listed in Table 6 together with those of the other kinetic and thermodynamic parameters. One can see that $k_{d}$ progressively increased with temperature from 0.0030 to $0.0227 \mathrm{~min}^{-1}$, which means that denaturation 
became progressively more significant, likely due to the breaking of an increasing number of strong electrostatic bonds.

Table 6. Kinetic and thermodynamic parameters of thermal denaturation of crude Aspergillus tamarii URM4634 protease produced by sequential fermentation using wheat bran as a substate.

\begin{tabular}{|c|c|c|c|c|c|c|c|c|c|}
\hline $\begin{array}{c}\mathrm{T} \\
\left({ }^{\circ} \mathrm{C}\right)\end{array}$ & $\begin{array}{c}{ }^{a} k_{d} \\
\left(\min ^{-1}\right)\end{array}$ & $\mathbf{R}^{2}$ & $\begin{array}{l}\mathrm{b}_{\mathrm{t}_{1 / 2}} \\
(\mathrm{~min})\end{array}$ & $\begin{array}{l}{ }^{c} \text { D-Value } \\
\text { (min) }\end{array}$ & $\begin{array}{c}{ }^{d} \text { Z-Value } \\
\left({ }^{\circ} \mathrm{C}\right)\end{array}$ & $\begin{array}{c}\mathrm{e}^{\mathrm{e}} \mathrm{E}_{\mathrm{d}} \\
\left(\mathrm{kJ} \mathrm{mol}{ }^{-1}\right)\end{array}$ & $\begin{array}{c}{ }^{\mathrm{f}} \Delta \mathrm{G}^{*} \mathrm{~d} \\
\left(\mathrm{~kJ} \mathrm{~mol}{ }^{-1}\right)\end{array}$ & $\begin{array}{c}{ }^{\mathrm{g}} \Delta \mathrm{H}^{*}{ }_{\mathrm{d}} \\
\left(\mathrm{kJ} \mathrm{mol}{ }^{-1}\right)\end{array}$ & $\begin{array}{c}{ }^{\mathrm{h}} \Delta S^{*}{ }_{\mathrm{d}} \\
\left(\mathrm{J} \mathrm{mol} \mathrm{mol}^{-1} \mathrm{~K}^{-1}\right)\end{array}$ \\
\hline 50 & 0.0030 & 0.979 & 231.05 & 767.53 & \multirow{4}{*}{33.89} & \multirow{4}{*}{64.78} & 105.97 & 62.09 & -135.76 \\
\hline 60 & 0.0083 & 0.969 & 83.51 & 277.42 & & & 106.51 & 62.01 & -133.57 \\
\hline 70 & 0.0170 & 0.997 & 40.77 & 135.45 & & & 107.75 & 61.93 & -133.52 \\
\hline 80 & 0.0227 & 0.998 & 30.53 & 101.43 & & & 110.12 & 61.84 & -136.71 \\
\hline
\end{tabular}

${ }^{a}$ First-order inactivation rate constant; ${ }^{b}$ Half-life; ${ }^{c}$ Decimal reduction time; ${ }^{\mathrm{d}}$ Thermal resistance constant; ${ }^{\mathrm{e}}$ Activation energy of thermal denaturation; ${ }^{\mathrm{f}}$ Activation Gibbs free energy of thermal denaturation; ${ }^{\mathrm{g}}$ Activation enthalpy of thermal denaturation, and ${ }^{\mathrm{h}}$ Activation entropy of thermal denaturation.

At $50{ }^{\circ} \mathrm{C}$, a temperature commonly used in several industrial processes, the crude protease obtained by SF exhibited much longer half-life $\left(\mathrm{t}_{1 / 2}=231.05 \mathrm{~min}\right)$ and decimal reduction time $(\mathrm{D}$-value $=767.53 \mathrm{~min}$ ) than that produced by the same fungal strain and substrate by SSF, either in crude $\left(\mathrm{t}_{1 / 2}: 96.3 \mathrm{~min}\right.$; D-value: $\left.319.9 \mathrm{~min}\right)$ or purified $\left(t_{1 / 2}: 70 \mathrm{~min}\right.$; D-value: $\left.232.6 \mathrm{~min}\right)$ form [37]. These results indicate that the protease produced by SF is more thermostable than that obtained by SSF; therefore, one of the next efforts will be an enzyme structural analysis that can provide some additional information for a better understanding of the thermostabilization mechanism under SF conditions. Moreover, the protease produced in the present study appears to be more thermostable than other Aspergillus proteases at same temperature $\left(50{ }^{\circ} \mathrm{C}\right)$, such as those produced by A. fumigatus ( $\mathrm{t}_{1 / 2}: 96.3 \mathrm{~min}$ ) [28], A. niger ( $\mathrm{t}_{1 / 2}: 135.91 \mathrm{~min}$; D-value: $451.49 \mathrm{~min}$ ) [30] and A. heteromorphus ( $\mathrm{t}_{1 / 2}$ : $54.6 \mathrm{~min}$; D-value: $\left.181.3 \mathrm{~min}\right)$ [20].

As proof of protease thermostability, a thermal resistance constant (Z-value) of $33.89^{\circ} \mathrm{C}$ was estimated with good correlation $\left(R^{2}=0.945\right)$ from the slope of the semi-log plot of Dvalue versus temperature (data not shown). In general, high Z-values, such as that obtained in the present study, indicate a greater sensitivity to the duration of the heat treatment than to the temperature increase [35]. The Z-value obtained is lower than that detected for the protease produced by SSF either in crude $\left(44.2^{\circ} \mathrm{C}\right)$ or purified $\left(75.8^{\circ} \mathrm{C}\right)$ form [37], which suggests a noticeable reduction in sensitivity to duration of thermal treatment when the enzyme is produced by SF.

As for the thermodynamic parameters of protease thermal denaturation, an activation energy $\left(\mathrm{E}_{\mathrm{d}}^{*}\right)$ of $64.78 \mathrm{~kJ} \mathrm{~mol}^{-1}$ was estimated from the Arrhenius-type plot illustrated in Figure 5 with satisfactory correlation $\left(R^{2}=0.955\right)$. As known, $E_{d}^{*}$ is related to the activation enthalpy of thermal denaturation $\left(\Delta \mathrm{H}_{\mathrm{d}}^{*}\right)$, i.e., the total amount of thermal energy required to denature the enzyme through disruption of non-covalent bonds, including hydrophobic interactions [31], which varied between 61.84 and $62.09 \mathrm{~kJ} \mathrm{~mol}^{-1}$. Comparison of the above $\mathrm{E}_{\mathrm{d}}^{*}$ and $\Delta \mathrm{H}_{\mathrm{d}}^{*}$ values with those of protease obtained by SSF either in crude $\left(\mathrm{E}_{\mathrm{d}}^{*}=49.7 \mathrm{~kJ} \mathrm{~mol}^{-1} ; \Delta \mathrm{H}_{\mathrm{d}}^{*}=46.7-47.0 \mathrm{~kJ} \mathrm{~mol}^{-1}\right)$ or purified $\left(\mathrm{E}_{\mathrm{d}}^{*}=28.8 \mathrm{~kJ} \mathrm{~mol}^{-1}\right.$; $\Delta \mathrm{H}_{\mathrm{d}}^{*}=25.9-26.1 \mathrm{~kJ} \mathrm{~mol}^{-1}$ ) form [37] confirms the higher thermostability of the enzyme produced by SF. To the best of our knowledge, studies comparing the thermostability of enzymes produced by different fermentation processes are very scarce. Nonetheless, the work of Saqib et al. [38] can be cited, in which the authors reported, on the basis of kinetic and thermodynamic parameters, a greater thermostability of an A. fumigatus endoglucanase produced by SSF rather than by SmF. Therefore, further studies are needed to investigate possible structural differences in enzymes produced in different fermentation processes, including unconventional methods such as SF. 


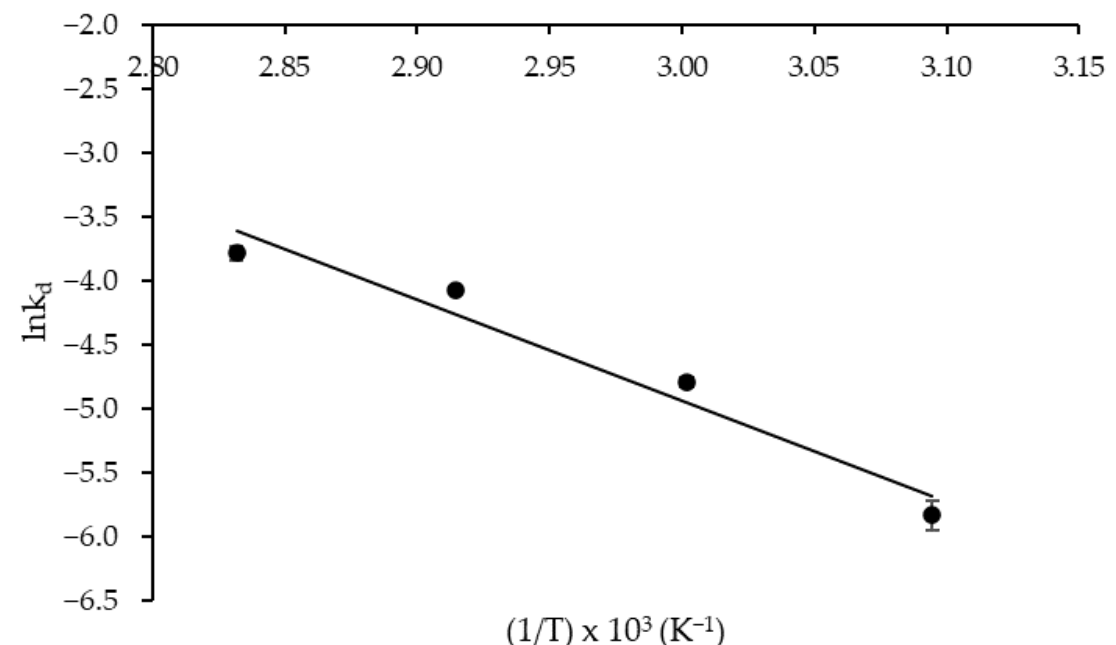

Figure 5. Arrhenius-type plot used to estimate the activation energy of thermal denaturation of Aspergillus tamarii URM4634 protease produced by sequential fermentation using wheat bran as a substrate.

Usually, a breakdown of the enzyme structure occurs during thermal denaturation, which is accompanied by an increase in the degree of disorder or randomness, i.e., a positive value of the activation entropy $\left(\Delta S^{*}\right)$ [28]. However, negative values of $\Delta S^{*}{ }_{d}$ of thermal denaturation ranging from -133.52 to $-136.71 \mathrm{~J} \mathrm{~mol}^{-1} \mathrm{~K}^{-1}$ were estimated for A. tamarii URM4634 protease produced by SF, suggesting an even higher order degree of the transition state compared to the separate reactants and then, high thermostability in the investigated range of temperature [39]. When $\Delta S$ is negative and $\Delta H$ positive, a process is not spontaneous at any temperature, but the reverse process is [29], which means that protease denaturation was reversible and not spontaneous at all temperatures investigated. As for the Gibbs free energy of thermal denaturation $\left(\Delta G^{*}\right)$, small or negative values of this parameter are related to a more spontaneous process; contrariwise, large or positive values like those estimated in this study $\left(105.97 \leq \Delta \mathrm{G}^{*} \mathrm{~d} \leq 110.12 \mathrm{~kJ} \mathrm{~mol}^{-1}\right)$ indicate special resistance to denaturation, confirming the thermostability indicated by the other kinetic and thermodynamic parameters.

\section{Materials and Methods}

\subsection{Materials}

Azocasein was purchased from Sigma-Aldrich (St. Louis, MO, USA). Potato dextrose agar (PDA) medium, glucose, yeast extract and all other reagents used were analytical grade. Wheat bran used as a substrate in SmF and SF was acquired in a local market in the city of Garanhuns, PE, Brazil.

\subsection{Microorganism and Inoculum Preparation}

The Aspergillus tamarii URM4634 strain was provided by the "Micoteca-URM" of Mycology Department, Centre of Biosciences of Federal University of Pernambuco (UFPE), Recife, PE, Brazil, preserved in mineral oil and maintained at $25 \pm 1^{\circ} \mathrm{C}$ in Czapek Dox agar medium. For sporulation, the strain was inoculated in PDA medium for 7 days at $30{ }^{\circ} \mathrm{C}$. The spores were suspended in $\mathrm{NaCl}$ solution $(0.9 \%)$ containing Tween $80(0.01 \%)$, and the inoculum was adjusted to a final concentration of $10^{5}$ spores $\mathrm{mL}^{-1}$ and $10^{7}$ spores $\mathrm{g}^{-1}$ of substrate for the initial SmF and SF runs, respectively.

\subsection{Protease Production by Sequential Fermentation}

The sequential fermentation (SF) was performed at $30{ }^{\circ} \mathrm{C}$ in two steps. First the solidstate fermentation (SSF) was conducted for $24 \mathrm{~h}$, then the nutrient medium was added, and the submerged fermentation $(\mathrm{SmF})$ was carried out for the same time. The fermentation 
was performed in $250 \mathrm{~mL}$-Erlenmeyer flasks containing $5 \mathrm{~g}$ of substrate (wheat bran standardized to a particle size between 0.5 and $2.0 \mathrm{~mm})$, nutrition solution $(1.0 \%$ glucose and $0.5 \%$ yeast extract) and a spore suspension $\left(10^{7}\right.$ spores $\left.\mathrm{g}^{-1}\right)$, corresponding to a $60 \%$ moisture content. After $24 \mathrm{~h}$ of growth, we added, in the proportion of $20 \mathrm{~mL} \mathrm{~g}^{-1}$ of substrate, a nutrient medium adapted from Cunha et al. [7] having the following composition: $0.14 \%\left(\mathrm{NH}_{4}\right)_{2} \mathrm{SO}_{4}, 0.20 \% \mathrm{KH}_{2} \mathrm{PO}_{4}, 0.03 \% \mathrm{CaCl}_{2}, 0.02 \% \mathrm{MgSO}_{4} \cdot 7 \mathrm{H}_{2} \mathrm{O}, 0.50 \%$ peptone, $0.20 \%$ yeast extract, $0.03 \%$ urea, $0.10 \%$ Tween $80,0.10 \%$ mineral solution $\left(5 \mathrm{mg} \mathrm{L}^{-1}\right.$ $\mathrm{FeSO}_{4} \cdot 7 \mathrm{H}_{2} \mathrm{O}, 1.6 \mathrm{mg} \mathrm{L}{ }^{-1} \mathrm{MnSO}_{4} \cdot \mathrm{H}_{2} \mathrm{O}$ and $\left.1.4 \mathrm{mg} \mathrm{L}^{-1} \mathrm{ZnSO}_{4} \cdot 7 \mathrm{H}_{2} \mathrm{O}\right)$ and supplemented with glucose $\left(40.0 \mathrm{~g} \mathrm{~L}^{-1}\right)$. After $24 \mathrm{~h}$ of $\mathrm{SmF}$ carried out under stirring (150 rpm), the fermented medium was filtered with a vacuum pump, and the crude enzyme extract was stored at $-20^{\circ} \mathrm{C}$ for further analysis.

Protease production by SF was investigated using a $2^{3}$-full factorial design plus four central points, in which glucose concentration $\left(30,40\right.$ and $\left.50 \mathrm{~g} \mathrm{~L}^{-1}\right)$, medium volume (15, 20 and $25 \mathrm{~mL} \mathrm{~g}^{-1}$ of substrate) and inoculum size $\left(10^{6}, 10^{7}\right.$ and $10^{8}$ spores $^{-1}$ of substrate) were selected as the independent variables (Table 1). Based on the results obtained with this statistical design (Table 2), a central composite rotational design (CCRD) was performed to better identify the experimental conditions to maximize protease production, in which the independent variables were glucose concentration and medium volume (Table 3).

The statistical analysis of both experimental designs was performed using the software package Statistica 7.0 (Statsoft Inc., Tulsa, OK, USA). The best fitting quadratic model equation was determined by the Fisher's test. The fitting ability of the model was assessed by the coefficient of determination $\left(\mathrm{R}^{2}\right)$ and the analysis of variance (ANOVA).

\subsection{Protease Production by Submerged Fermentation}

For comparison purposes, submerged fermentations were also performed at $130 \mathrm{rpm}$ and $30{ }^{\circ} \mathrm{C}$ for $48 \mathrm{~h}$, according to Porto et al. [40] with some modifications, using wheat flour as a substrate in $250 \mathrm{~mL}$-Erlenmeyer flasks containing $50 \mathrm{~mL}$ of culture medium with the following composition (\%): filtered wheat flour, 4.0; $\mathrm{NH}_{4} \mathrm{Cl}, 0.1 ; \mathrm{MgSO}_{4} \cdot 7 \mathrm{H}_{2} \mathrm{O}, 0.06$; yeast extract, $0.1 ; \mathrm{K}_{2} \mathrm{HPO}_{4}, 0.435$; glucose, 0.5 ; and $1.0 \%\left(\mathrm{v} \mathrm{v}^{-1}\right)$ mineral solution $(100 \mathrm{mg}$ $\mathrm{FeSO}_{4} \cdot 7 \mathrm{H}_{2} \mathrm{O} ; 100 \mathrm{mg} \mathrm{MnCl} 2 \cdot 4 \mathrm{H}_{2} \mathrm{O}$; and $100 \mathrm{mg} \mathrm{ZnSO} \cdot \mathrm{H}_{2} \mathrm{O}$ in $100 \mathrm{~mL}$ of distilled water). The medium $\mathrm{pH}$ was adjusted to 7.0 before fermentation.

\subsection{Analytical Determinations}

Protease activity was determined as described by Ginther [41] with adaptations using azocasein as a substrate. For this purpose, a 1.0\% azocasein solution was prepared in Tris- $\mathrm{HCl}$ buffer $(0.2 \mathrm{M}, \mathrm{pH} 7.2)$ containing $1.0 \mathrm{mM} \mathrm{CaCl}_{2}$. The reaction was performed using $0.15 \mathrm{~mL}$ of enzyme extract and $0.25 \mathrm{~mL}$ of azocasein solution at room temperature $\left(25 \pm 1^{\circ} \mathrm{C}\right)$. After $1 \mathrm{~h}$, the reaction was stopped by addition of $1.0 \mathrm{~mL}$ of $10 \%$ trichloroacetic acid (TCA). Then, the samples were centrifuged at $8000 \times g$ for $20 \mathrm{~min}$ at $4{ }^{\circ} \mathrm{C}, 0.8 \mathrm{~mL}$ of supernatant were added to $0.2 \mathrm{~mL}$ of $1.8 \mathrm{M} \mathrm{NaOH}$, and the absorbance of samples was measured at $420 \mathrm{~nm}$ with a spectrophotometer (Biochrom Libra S6, Cambridge, UK). Protease activity was defined as the enzyme amount responsible for a 0.1 increase in absorbance at $420 \mathrm{~nm}$ within $1 \mathrm{~h}$. The total protein concentration was determined by the Bradford method [42] using bovine serum albumin (BSA) as a standard.

\subsection{Effect of $\mathrm{pH}$ and Temperature on Protease Activity}

The optimum $\mathrm{pH}$ of enzyme activity was determined through activity tests carried out at $25^{\circ} \mathrm{C}$ as described in the previous section using substrate solutions at $\mathrm{pH}$ values ranging from 5.0 to 12.0. For this purpose, the following buffers were used at $0.1 \mathrm{M}$ concentration: citrate-phosphate (5.0-7.0), Tris- $\mathrm{HCl}$ (7.0-9.0) and glycine- $\mathrm{NaOH}$ (9.0-12.0). On the other hand, the influence of temperature on protease activity was investigated through activity tests carried out at different temperatures $\left(30-80^{\circ} \mathrm{C}\right)$ and constant $\mathrm{pH}(7.2)$. The results were evaluated by the Tukey's test to verify statistically significant differences $(p<0.05)$ among different samples at different values of $\mathrm{pH}$ or temperature. 


\subsection{Kinetic and Thermodynamic Parameters of Azocasein Hydrolysis}

The Michaelis constant $\left(\mathrm{K}_{\mathrm{m}}\right)$ and maximum rate $\left(\mathrm{V}_{\max }\right)$ of azocasein hydrolysis were estimated by the Lineweaver-Burk double reciprocal plot. For this purpose, protease activity assays were performed using different substrate concentrations $\left(2.0-100 \mathrm{mg} \mathrm{mL}^{-1}\right)$ at $\mathrm{pH} 7.2$ and $25 \pm 1^{\circ} \mathrm{C}$. The catalytic constant or turnover number $\left(\mathrm{k}_{\text {cat }}\right)$ was calculated as the ratio of $\mathrm{V}_{\max }$ to the protein concentration. The activation energy $\left(\mathrm{E}_{\mathrm{a}}^{*}\right)$ of substrate hydrolysis was estimated by the Arrhenius-type plot of $\ln \mathrm{A}_{0}$ versus $1 / \mathrm{T}$, being $\mathrm{A}_{0}$ the starting activity and $\mathrm{T}$ the absolute temperature, using the results of enzyme activity tests. For a better understanding of temperature influence on the hydrolysis reaction, the temperature quotient $\left(\mathrm{Q}_{10}\right)$, which is the factor by which the enzyme activity increases due to a $10{ }^{\circ} \mathrm{C}$ temperature increase, was calculated by the following equation [43]:

$$
\mathrm{Q}_{10}=\operatorname{anti} \log \left(\frac{\mathrm{E}_{\mathrm{a}}^{*} \times 10}{\mathrm{RT}^{2}}\right)
$$

where $\mathrm{R}$ is the gas constant $\left(8.314 \mathrm{~J} \mathrm{~mol}^{-1} \mathrm{~K}^{-1}\right)$.

The thermodynamic parameters, namely the activation enthalpy $\left(\Delta \mathrm{H}^{*}\right)$, Gibbs free energy $\left(\Delta \mathrm{G}^{*}\right)$ and entropy $\left(\Delta \mathrm{S}^{*}\right)$ of azocasein hydrolysis, were calculated using the following equations:

$$
\begin{gathered}
\Delta \mathrm{H}^{*}=\mathrm{E}_{\mathrm{a}}^{*}-\mathrm{RT} \\
\Delta \mathrm{G}^{*}=-\mathrm{RT} \ln \left(\frac{\mathrm{k}_{\mathrm{cat}} \mathrm{h}}{\mathrm{k}_{\mathrm{b}} \mathrm{T}}\right) \\
\Delta \mathrm{S}^{*}=\frac{\Delta \mathrm{H}^{*}-\Delta \mathrm{G}^{*}}{\mathrm{~T}}
\end{gathered}
$$

where $\mathrm{h}\left(6.626 \times 10^{-34} \mathrm{~J} \mathrm{~s}\right)$ is the Planck constant, $\mathrm{k}_{\mathrm{b}}\left(1.381 \times 10^{-23} \mathrm{~J} \mathrm{~K}^{-1}\right)$ the Boltzmann constant and $T$ is the reference temperature $(298.15 \mathrm{~K})$.

\subsection{Kinetic and Thermodynamic Parameters of Protease Thermal Denaturation}

As known, the increase in temperature not only accelerates the enzyme reaction but also promotes the reversible enzyme unfolding and the subsequent denaturation of its structure [31]. The enzyme thermal denaturation can then be kinetically described by the equation:

$$
\frac{\mathrm{dA}}{\mathrm{dt}}=-\mathrm{k}_{\mathrm{d}} \cdot \mathrm{A}
$$

where $k_{d}$ is the rate constant of denaturation, A the enzyme activity and $t$ the time.

Accordingly, the $k_{d}$ values were estimated through the linearized version of this equation:

$$
\ln \left(\frac{\mathrm{A}}{\mathrm{A}_{0}}\right)=-\mathrm{k}_{\mathrm{d}} \mathrm{t}
$$

from the slopes of the straight lines obtained by plotting the experimental data of $\ln \left(\mathrm{A} / \mathrm{A}_{0}\right)$ versus time in the temperature range of 50 to $80^{\circ} \mathrm{C}$, where $A_{0}$ is the starting activity at $\mathrm{t}=0$.

From the $k_{d}$ values, we also calculated the half-life $\left(t_{1 / 2}\right)$, which is defined as the time after which the enzyme activity is reduced to one-half the initial value:

$$
\mathrm{t}_{1 / 2}=\frac{\ln 2}{\mathrm{k}_{\mathrm{d}}}
$$

and the decimal reduction time (D-value), i.e., the time required for a 10-fold activity reduction:

$$
\mathrm{D}-\text { value }=\frac{\ln 10}{\mathrm{k}_{\mathrm{d}}}
$$


The D-value is often accompanied by the thermal resistance constant (Z-value) that corresponds to the temperature increase required to achieve a 10-fold reduction of the D-value. This parameter was estimated from the slope of the thermal death time plot of $\log \mathrm{D}$ versus $\mathrm{T}\left({ }^{\circ} \mathrm{C}\right)$.

The thermodynamic parameters related to protease thermal denaturation were also estimated from an Arrhenius-type plot. Particularly, the activation energy $\left(E_{d}^{*}\right)$ was estimated from the slope of the straight line of $l n k_{d}$ vs. $1 / T$, while the activation enthalpy $\left(\Delta \mathrm{H}_{\mathrm{d}}{ }_{\mathrm{d}}\right)$, Gibbs free energy $\left(\Delta \mathrm{G}_{\mathrm{d}}^{*}\right)$ and entropy $\left(\Delta \mathrm{S}_{\mathrm{d}}{ }_{\mathrm{d}}\right)$ were calculated similarly to those of enzyme-catalyzed reaction using $\mathrm{k}_{\mathrm{d}}$ instead of $\mathrm{k}_{\mathrm{cat}}$ in Equations (2)-(4).

\section{Conclusions}

The sequential fermentation (SF) process proved to be an interesting approach for protease production, showing higher outcomes $\left(180.17 \mathrm{U} \mathrm{mL}^{-1}\right)$ compared to the conventional submerged fermentation $\left(20.0 \mathrm{U} \mathrm{mL}^{-1}\right)$. Several differences in the enzyme characteristics, especially an improved thermostability, were observed compared to the protease obtained in a previous study by solid-state fermentation using the same fungal strain and substrate, thereby indicating the need to carry out further studies on the protein structure for a better understanding of SF features. The enzyme produced has been classified as a neutral protease (optimum $\mathrm{pH}$ of 7.0), which would offer several advantages in typical food industry applications such as baking and brewing processes. Moreover, the kinetic and thermodynamic study pointed out a satisfactory thermostability of the protease at $50{ }^{\circ} \mathrm{C}$, a temperature commonly used in many industrial processes, evidenced especially by a half-life of $231.05 \mathrm{~min}$ and a decimal reduction time of $767.53 \mathrm{~min}$. The results obtained in this study can contribute to the development of the SF technique to produce proteases and various other enzymes of industrial interest.

Author Contributions: Conceptualization, R.L.d.O., A.C. and T.S.P.; methodology, R.L.d.O., A.C. and T.S.P.; software, R.L.d.O. and T.S.P.; validation, A.C. and T.S.P.; formal analysis, R.L.d.O., E.d.S.C. and T.S.P.; investigation, R.L.d.O. and E.d.S.C.; resources, T.S.P.; data curation, R.L.d.O. and A.C.; writing — original draft preparation, R.L.d.O. and E.d.S.C.; writing—review and editing, R.L.d.O., A.C. and T.S.P.; visualization, A.C. and T.S.P.; supervision, R.L.d.O.; project administration, T.S.P.; funding acquisition, T.S.P. All authors have read and agreed to the published version of the manuscript.

Funding: This research was funded by the Coordenacão de Aperfeicoamento de Pessoal de Nível Superior (CAPES, Brazil) grant number 23038.003634/2013-15 and the National Council for Scientific and Technological Development (CNPq, Brazil) grant number 471773/2013-1.

Data Availability Statement: The data presented in this study are available on request from the corresponding author.

Acknowledgments: Rodrigo Lira de Oliveira is grateful to FACEPE (Foundation for Science and Technology of the State of Pernambuco, Brazil) for his post-doctoral scholarship (grant BFP-01055.07/20). The authors are grateful to the Coordenacão de Aperfeicoamento de Pessoal de Nível Superior (CAPES, Brazil) and the National Council for Scientific and Technological Development (CNPq, Brazil) for financial funding, and the Federal Rural University of Pernambuco for the laboratory infrastructure.

Conflicts of Interest: The authors declare no conflict of interest.

\section{References}

1. Naveed, M.; Nadeem, F.; Mehmood, T.; Bilal, M.; Anwar, Z.; Amjad, F. A versatile and ecofriendly biocatalyst with multi-industrial applications: An updated review. Catal. Lett. 2020, 151, 307-323. [CrossRef]

2. Gurumallesh, P.; Alagu, K.; Ramakrishnan, B.; Muthusamy, S. A systematic reconsideration on proteases. Int. J. Biol. Macromol. 2019, 128, 254-267. [CrossRef]

3. Sharma, K.M.; Kumar, R.; Panwar, S.; Kumar, A. Microbial alkaline proteases: Optimization of production parameters and their properties. J. Genet. Eng. Biotechnol. 2017, 15, 115-126. [CrossRef] [PubMed]

4. Soccol, C.R.; da Costa, E.S.F.; Letti, L.A.J.; Karp, S.G.; Woiciechowski, A.L.; Vandenberghe, L.P.S. Recent developments and innovations in solid state fermentation. Biotechnol. Res. Innov. 2017, 1, 52-71. [CrossRef] 
5. Farinas, C.S. Developments in solid-state fermentation for the production of biomass-degrading enzymes for the bioenergy sector. Renew. Sustain. Energy Rev. 2015, 52, 179-188. [CrossRef]

6. Yazid, N.A.; Barrena, R.; Komilis, D.; Sánchez, A. Solid-State Fermentation as a novel paradigm for organic waste valorization: A review. Sustainability 2017, 9, 224. [CrossRef]

7. Cunha, F.M.; Esperança, M.N.; Zangirolami, T.C.; Badino, A.C.; Farinas, C.S. Sequential solid-state and submerged cultivation of Aspergillus niger on sugarcane bagasse for the production of cellulase. Bioresour. Technol. 2012, 112, 270-274. [CrossRef]

8. Farinas, C.S.; Florencio, C.; Badino, A.C. On-site production of cellulolytic enzymes by the sequential cultivation method. In Cellulases. Methods in Molecular Biology; Lübeck, M., Ed.; Humana Press: New York, NY, USA, 2018; Volume 1796, pp. 273-282. [CrossRef]

9. Florencio, C.; Cunha, F.M.; Badino, A.C.; Farinas, C.S.; Ximenes, E.; Ladisch, M.R. Secretome analysis of Trichoderma reesei and Aspergillus niger cultivated by submerged and sequential fermentation processes: Enzyme production for sugarcane bagasse hydrolysis. Enzyme Microb. Technol. 2016, 90, 53-60. [CrossRef]

10. Florencio, C.; Cunha, F.M.; Badino, A.C.; Farinas, C.S. Validation of a novel sequential cultivation method for the production of enzymatic cocktails from Trichoderma strains. Appl. Biochem. Biotechnol. 2014, 175, 1389-1402. [CrossRef]

11. An, Q.; Wu, X.; Han, M.; Chu, B.; He, S.; Dai, Y.; Si, J. Sequential Solid-State and Submerged Cultivation of the white rot fungus Pleurotus ostreatus on biomass and the activity of lignocellulolytic enzymes. BioResources 2016, 11, 8791-8805. [CrossRef]

12. Cunha, F.M.; Vasconcellos, V.M.; Florencio, C.; Badino, A.C.; Farinas, C.S. On-site production of enzymatic cocktails using a non-conventional fermentation method with agro-industrial residues as renewable feedstocks. Waste Biomass Valorization 2017, 8 , 517-526. [CrossRef]

13. Bankar, S.B.; Bule, M.V.; Singhal, R.S.; Ananthanarayan, L. Optimization of Aspergillus niger fermentation for the production of glucose oxidase. Food Bioprocess Technol. 2009, 2, 344-352. [CrossRef]

14. Ahmed, A.; Ejaz, U.; Sohail, M. Pectinase production from immobilized and free cells of Geotrichum candidum AA15 in galacturonic acid and sugars containing medium. J. King Saud Univ. Sci. 2020, 32, 952-954. [CrossRef]

15. Sun, H.; Ge, X.; Hao, Z.; Peng, M. Cellulase production by Trichoderma sp. on apple pomace under solid state fermentation. Afr. J. Biotechnol. 2010, 9, 163-166. [CrossRef]

16. Sandhya, C.; Sumantha, A.; Szakacs, G.; Pandey, A. Comparative evaluation of neutral protease production by Aspergillus oryzae in submerged and solid-state fermentation. Process Biochem. 2005, 10, 2689-2694. [CrossRef]

17. Robinson, P.K. Enzymes: Principles and biotechnological applications. Essays Biochem. 2015, 59, 1-41. [CrossRef]

18. Vitolo, M. Enzymes: The catalytic proteins. In Pharmaceutical Biotechnology, 1st ed.; Pessoa, A., Jr., Vitolo, M., Long, P.F., Eds.; CRC Press: Boca Raton, FL, USA, 2021; Volume 1, pp. 257-263. [CrossRef]

19. da Silva, O.S.; de Oliveira, R.L.; Souza-Motta, C.M.; Porto, A.L.F.; Porto, T.S. Novel protease from Aspergillus tamarii URM4634: Production and characterization using inexpensive agroindustrial substrates by Solid-State Fermentation. Adv. Enzym. Res. 2016, 4, 125-143. [CrossRef]

20. Fernandes, L.M.G.; Carneiro-da-Cunha, M.N.; Silva, J.C.; Porto, A.L.F.; Porto, T.S. Purification and characterization of a novel Aspergillus heteromorphus URM 0269 protease extracted by aqueous two-phase systems PEG/citrate. J. Mol. Liq. 2020, $317,113957$. [CrossRef]

21. de Castro, R.J.S.; Nishide, T.G.; Sato, H.H. Production and biochemical properties of proteases secreted by Aspergillus niger under solid state fermentation in response to different agroindustrial substrates. Biocatal. Agric. Biotechnol. 2014, 3, 236-245. [CrossRef]

22. Salihi, A.; Asoodeh, A.; Aliabadian, M. Production and biochemical characterization of an alkaline protease from Aspergillus oryzae CH93. Int. J. Biol. Macromol. 2017, 94, 827-835. [CrossRef]

23. Razzaq, A.; Shamsi, S.; Ali, A.; Ali, Q.; Sajjad, M.; Malik, A.; Ashraf, M. Microbial proteases applications. Front. Bioeng. Biotechnol. 2019, 7, 110. [CrossRef] [PubMed]

24. Tavano, O.L.; Berenguer-Murcia, A.; Secundo, F.; Fernandez-Lafuente, R. Biotechnological applications of proteases in food technology. Compr. Rev. Food Sci. Food Saf. 2018, 17, 412-436. [CrossRef] [PubMed]

25. Belmessikh, A.; Boukhalfa, H.; Mechakra-Maza, A.; Gheribi-Aoulmi, Z.; Amrane, A. Statistical optimization of culture medium for neutral protease production by Aspergillus oryzae. Comparative study between solid and submerged fermentations on tomato pomace. J. Taiwan Inst. Chem. Eng. 2013, 44, 377-385. [CrossRef]

26. Alves, R.O.; de Oliveira, R.L.; da Silva, O.S.; Porto, A.L.F.; Porto, C.S. Extractive fermentation for process integration of protease production by Aspergillus tamarii Kita UCP1279 and purification by PEG-Citrate Aqueous Two-Phase System. Prep. Biochem. Biotechnol. 2021, 1-8. [CrossRef]

27. Lee, S.K.; Hwang, J.Y.; Choi, S.H.; Kim, S.M. Purification and characterization of Aspergillus oryzae LK-101 salt-tolerant acid protease isolated from soybean paste. Food Sci. Biotechnol. 2010, 19, 327-334. [CrossRef]

28. Hernández-Martínez, R.; Gutiérrez-Sánchez, G.; Bergmann, C.W.; Loera-Corral, O.; Rojo-Domínguez, A.; Huerta-Ochoa, S.; Regalado-González, C.; Prado-Barragán, L.A. Purification and characterization of a thermodynamic stable serine protease from Aspergillus fumigatus. Process Biochem. 2011, 45, 2001-2006. [CrossRef]

29. Melikoglu, M.; Lin, C.S.K.; Webb, C. Kinetic studies on the multi-enzyme solution produced via solid state fermentation of waste bread by Aspergillus awamori. Biochem. Eng. J. 2013, 80, 76-82. [CrossRef] 
30. de Castro, R.J.S.; Ohara, A.; Nishide, T.G.; Albernaz, J.R.M.; Soares, M.H.; Sato, H.H. A new approach for proteases production by Aspergillus niger based on the kinetic and thermodynamic parameters of the enzymes obtained. Biocatal. Agric. Biotechnol. 2015, 4, 199-207. [CrossRef]

31. de Oliveira, R.L.; Silva, M.F.; Converti, A.; Porto, T.S. Biochemical characterization and kinetic/thermodynamic study of Aspergillus tamarii URM4634 $\beta$-fructofuranosidase with transfructosylating activity. Biotechnol. Prog. 2019, 35, 2879. [CrossRef]

32. Abdel-Naby, M.A.; Ahmed, S.A.; Wehaidy, H.R.; El-Mahdy, S.A. Catalytic, kinetic and thermodynamic properties of stabilized Bacillus stearothermophilus alkaline protease. Int. J. Biol. Macromol. 2017, 96, 265-271. [CrossRef] [PubMed]

33. Silva, J.C.; de França, P.R.L.; Converti, A.; Porto, T.S. Kinetic and thermodynamic characterization of a novel Aspergillus aculeatus URM4953 polygalacturonase. Comparison of free and calcium alginate-immobilized enzyme. Process Biochem. 2018, 74, 61-70. [CrossRef]

34. Mostafa, F.A.; Abdel, W.A.; Salah, H.A.; Nawwar, G.A.M.; Esawy, M.A. Kinetic and thermodynamic characteristic of Aspergillus awamori EM66 levansucrase. Int. J. Biol. Macromol. 2018, 119, 232-239. [CrossRef] [PubMed]

35. Converti, A.; Pessoa, A., Jr.; Silva, J.C.; de Oliveira, R.L.; Porto, T.S. Thermodynamics applied to biomolecules. In Pharmaceutical Biotechnology, 1st ed.; Pessoa, A., Vitolo, M., Long, P.F., Eds.; CRC Press: Boca Raton, FL, USA, 2021; Volume 1, pp. 27-42. [CrossRef]

36. Abdel-Naby, M.A.; El-Wafa, W.M.A.; Salem, G.E.M. Molecular characterization, catalytic, kinetic and thermodynamic properties of protease produced by a mutant of Bacillus cereus-S6. Int. J. Biol. Macromol 2020, 160, 695-702. [CrossRef] [PubMed]

37. da Silva, O.S.; de Oliveira, R.L.; Silva, J.C.; Converti, A.; Porto, T.S. Thermodynamic investigation of an alkaline protease from Aspergillus tamarii URM4634: A comparative approach between crude extract and purified enzyme. Int. J. Biol. Macromol. 2018, 109, 1039-1044. [CrossRef] [PubMed]

38. Saqib, A.A.N.; Hassan, M.; Khan, N.F.; Baig, S. Thermostability of crude endoglucanase from Aspergillus fumigatus grown under solid state fermentation (SSF) and submerged fermentation (SmF). Process Biochem. 2010, 45, 641-646. [CrossRef]

39. de Oliveira, R.L.; da Silva, O.S.; Converti, A.; Porto, T.S. Thermodynamic and kinetic studies on pectinase extracted from Aspergillus aculeatus: Free and immobilized enzyme entrapped in alginate beads. Int. J. Biol. Macromol. 2018, 115, 1088-1093. [CrossRef] [PubMed]

40. Porto, A.L.F.; Campos-Takaki, G.M.; Lima Filho, J.L. Effects of culture conditions on protease production by Streptomyces clavuligerus growing on soybean flour medium. Appl. Biochem. Biotechnol. 1996, 60, 115-122. [CrossRef]

41. Ginther, C.L. Sporulation and the production of serine protease and cephamycin C by Streptomyces lactamdurans. Antimicrob. Agents Chemother. 1979, 15, 522-526. [CrossRef]

42. Bradford, M.M. A rapid and sensitive method for the quantitation of microgram quantities of protein utilizing the principle of protein-dye binding. Anal. Biochem. 1976, 72, 248-254. [CrossRef]

43. Dixon, M.; Webb, C. Enzyme inhibition and inactivation. In Enzymes, 3rd ed.; Longman: London, UK, 1979 ; pp. $332-467$. 